Review of

ECONOMICS

and

INSTITUTIONS
Review of Economics and Institutions

ISSN 2038-1379 DOI 10.5202/rei.v6i1.136

Vol. 6 - No. 1, Winter-Spring 2015 - Article 3

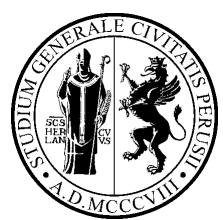

www.rei.unipg.it

\title{
What Explains Small and Medium-Sized Business Groups? Comparing the Financial and the Entrepreneurial Perspective
}

\author{
Donato Iacobucci $\bowtie$ \\ Enrico Guzzini \\ Peter Rosa \\ Polytechnic University of Marche eCampus University University of Edinburgh
}

\begin{abstract}
The paper contrasts two theoretical perspectives that account for business group formation in the small business sector: the financial perspective and the organizational/entrepreneurial perspective. Two main hypotheses are derived from these perspectives: the first hypothesis concerns capital and knowledge intensity required by the business; the second one refers to the entrepreneur's ownership of firms in business groups. The empirical results show that the financial and the organizational perspectives are both relevant in explaining business groups in the small business sector, but the entrepreneurial perspective is more appropriate when explaining the ownership structure of firms within business groups.
\end{abstract}

JEL classification: D22; M13; M21;

Keywords: business groups, small businesses, portfolio entrepreneurs, ownership, diversification

We would like to thank the Editors of this special issue and the anonymous referees for their helpful comments and suggestions. Usual disclaimer applies.

$\triangle$ Corresponding author. Address: Department of Information Engineering, Polytechnic University of Marche. Via Brecce Bianche 12, 60131 Ancona - Italy (Phone: +39071220 4482. Email: d.iacobucci@univpm.it).

\section{Recommended Citation}

Iacobucci, D., Guzzini, E., Rosa, P. (2015). What Explains Small and Medium-Sized Business Groups? Comparing the Financial and the Entrepreneurial Perspective. Review of Economics and Institutions, 6(1), Article 3. doi: 10.5202/rei.v6i1.136.

Retrieved from http://www.rei.unipg.it/rei/article/view/136 


\section{Introduction}

A business group is a set of firms owned and controlled by the same people by means of ownership ties. Interest in studying business groups has grown, as a result of an increased awareness of their widespread presence and economic importance in both emerging and developed countries. In the small business sector business groups are associated with 'portfolio entrepreneurs' i.e. habitual entrepreneurs who retain ownership and control of previously established businesses thus leading to the formation of business groups.

Most of the literature on business groups has referred to large corporate groups, sometimes the largest in a country, but there is increasing awareness that portfolio entrepreneurs and business groups are widespread in all sectors and size classes and are relevant also in the small business sector. The presence of business groups in the small business sector suggests that their development may be associated with entrepreneurial processes, and particularly with the activities and strategic behaviours of habitual entrepreneurs (Rosa, 1998; Iacobucci and Rosa, 2005 and 2010).

In the present study we define business groups in terms of ownership and control ties. We would not deny the importance of other forms of relations among firms that are not based on ownership ties, but we adopt that definition here both because it gives clearer and more objective guidance to delimit the boundaries of the group and it is suited to the aims of this study. ${ }^{1}$ There is a large literature explaining the presence of business groups. Most of this literature refers to emerging countries and considers the group to be a substitute for the deficiency of market institutions and imperfect information flows, the so-called institutional voids theory $\left.\right|^{2}$ In the case of advanced economies, where such deficiencies are less marked, groups have been seen mainly as financial devices to separate control and cash-flow rights. The main aim of this paper is to compare the financial explanation with an alternative explanation based on entrepreneurial/organizational reasons. The financial and entrepreneurial perspectives analysed in this paper are not conflicting with the institutional voids theory put forward to explain the presence of business groups in emerging economies. We focus on the first two explanations as our empirical analysis refers to business groups in an advanced economy.

Moreover, we focus on small and medium sized groups which are less

1 This is the same definition normally adopted in the economics and business literature (Lhuillery, 2011). The definition of business group used in this paper is also the one normally adopted by statistical agencies (Eurostat 2003) and by the financial accounting standards for delimiting the area of consolidation when drawing consolidated financial statements.

2 It is beyond the scope of this paper to review this literature: see Colpan et al. (2010) for an up-to-date survey. 
researched. The small business and portfolio entrepreneurship ${ }^{3}$ literature has concentrated on the entrepreneur, who is assumed to be the main agent for establishing the business group. Research has found that establishing or expanding a business group is a common way for entrepreneurs to develop a new business. Up to a third of smaller limited companies may be part of multiple venture creation activities by their founder entrepreneurs These entrepreneurs demonstrate a preference for establishing additional new ventures, rather than focusing on growing a single business into a large one. Several studies have explored the differences between novice, habitual and portfolio entrepreneurs and how these differences may influence new business performance.

One of the key research questions is why and when portfolio entrepreneurs decide to set up a new firm to develop a new business rather than exploiting the new opportunity within the already established company. On a theoretical basis there are two main competing views on this issue.

First, the financial explanation put forward by several authors stresses the importance of raising outside equity to explain the creation of a new firm when exploiting a new business opportunity. Second, the entrepreneurial/organizational explanation which emphasizes the fact that legal autonomy allows entrepreneurs to involve other people in the ownership of the new business. By involving other people in the start-up of new ventures, entrepreneurs enhance their ability to exploit new business opportunities by mobilizing and motivating specialized human capital resources.

Both explanations offer useful insights for understanding the presence of portfolio entrepreneurs in the small firm sector, but they differ in their basic assumptions and consequent results. This paper aims at comparing, on an empirical basis, the predictions of these two perspectives. It takes advantage of an Italian survey of manufacturing firms that contains information on business groups. To our best knowledge this paper is the first attempt at empirically testing and comparing the predictions of the financial and the entrepreneurial perspectives on business groups in the small business sector ${ }^{4}$ and the first to consider how far the two perspectives link with each other.

The paper makes the following contributions. We show that the financial and the organizational perspectives can be considered to some extent complementary in explaining the presence of business groups. Specifically, the financial explanation is in accordance with the data in predicting the presence of larger and capital intensive firms in business groups while the organizational explanation is in accordance with empirical evidence in pre-

\footnotetext{
3 We follow the definitions of Birley and Westhead (1994), where an habitual entrepreneur is one that starts more than one business. A portfolio entrepreneur starts and retains ownership and control of several businesses. In contrast a serial entrepreneur only owns one business at a time, always closing a business before starting another one.

4 Also Almeida et al. (2011) test some hypothesis derived from the financial perspective; however, they refer to large listed groups in Korea.
} 
dicting the presence of knowledge intensive firms in business groups. Finally, the organizational perspective is more appropriate when explaining the ownership structure of controlled companies.

The paper is organized as follows. In Section 2 we review the theoretical literature on business groups, discuss in more detail the theoretical predictions of the financial and organizational approaches, and present the hypotheses to be tested. Section 3 discusses the methodology and describes the dataset used in the empirical part. Section 4 presents and discusses the results while Section 5 draws conclusions and suggests future research possibilities.

\section{Theoretical issues and research questions}

Business groups are the results of established entrepreneurs setting up or acquiring new companies. The empirical evidence shows that setting up a new firm is a common approach of established entrepreneurs when pursuing new business opportunities $\sqrt[5]{5}$ We lack detailed data on the prevalence of business groups in different countries; but business groups are relevant in all the industrialized countries and also in the small business sector. Moreover, the frequency of business groups appears to be increasing

According to the latest information provided by ISTAT (the Italian National Statistics Agency) in Italy there were in 2010 more than 80 thousands business groups, controlling about 180,000 companies and with 5.7 million employees They represent more than a third of the overall employees in the private sector and more than a half of the employees of joint stock companies. Moreover, the number of companies and employees of business groups is underestimated as they refer only to the companies located in Italy.

Table 1 - Business Groups in Italy - 2010

\begin{tabular}{|c|c|c|c|c|c|c|c|c|c|}
\hline \multirow{2}{*}{$\begin{array}{l}\text { Class of } \\
\text { employees } \\
\text { of groups }\end{array}$} & \multicolumn{2}{|c|}{ Groups } & \multicolumn{2}{|c|}{$\begin{array}{l}\text { Employees } \\
\text { (thousands) }\end{array}$} & \multicolumn{2}{|c|}{ Firms* } & \multirow{2}{*}{$\begin{array}{l}\text { Average } \\
\text { firms per } \\
\text { group }\end{array}$} & \multirow{2}{*}{$\begin{array}{c}\text { Average } \\
\text { employees } \\
\text { per firm }\end{array}$} & \multirow{2}{*}{$\begin{array}{l}\text { Average } \\
\text { employees } \\
\text { per group }\end{array}$} \\
\hline & Number & $\%$ & Number & $\%$ & Number & $\%$ & & & \\
\hline $1-19$ & 54,624 & 66.4 & 359 & 6.3 & 100,216 & 54.1 & 1.8 & 3.6 & 6.5 \\
\hline $20-99$ & 20,566 & 25.0 & 882 & 15.5 & 51,715 & 27.9 & 2.5 & 17.1 & 42.9 \\
\hline $100-499$ & 5,676 & 6.9 & 1,156 & 20.3 & 21,390 & 11.6 & 3.8 & 54.0 & 203.0 \\
\hline 500-4999 & 1,316 & 1.6 & 1,594 & 28.0 & 10,129 & 5.5 & 7.7 & 161.6 & $1,240.5$ \\
\hline 5000 e oltre & 82 & 0.1 & 1,702 & 29.9 & 1,700 & 0.9 & 20.6 & 731.5 & $15,082.8$ \\
\hline TOTAL & 82,265 & 100 & 5,693 & 100 & 185,149 & 100.0 & 2.3 & 30.7 & 69.2 \\
\hline
\end{tabular}

* The number of firms per group is underestimated as they refer only to firms located in Italy Source: ISTAT

Most of groups have less than 500 employees; they control almost 95\% of

5 For an established entrepreneur the alternative way would be to develop the new business within his/her established firm. 
the companies and about $40 \%$ of the overall employees. As observed also in other developed countries, the phenomenon of business groups is relevant also among small and medium sized firms. ${ }^{6}$

To explain when and why a growth strategy results in the formation of a business group, we need to examine the specific advantages of giving legal autonomy to organizational units created to develop a new business. One of the main advantages is that setting up a new legal entity allows entrepreneurs to differentiate the ownership structure of the new activity from the established one(s), thus allowing equity capital to be raised from minority shareholders.

There are two main theoretical approaches to explain why entrepreneurs prefer to differentiate ownership in this way. The first (we term the financial perspective) stresses the raising of outside equity to maximize the return on the capital invested by the entrepreneur, made possible by having a separate legal unit. The second (we term the organisational perspective) considers the involvement of other people in the ownership of the new business in order to enlarge the entrepreneurial team; this is done by recruiting and engaging expertise without diluting ownership of the main business(es). These two explanations have different implications for the ownership structure of the new business and the role played by the providers of outside equity.

Within the financial perspective business groups are considered as a mechanism for separating cash-flow rights from control rights which allows, for example, family business owners to control and grow large companies with little investment. ${ }^{7}$ This approach has been traditionally applied to large, publicly traded, firms. It is unclear to what extent this explanation is valid in the case of smaller firms. Referring to family firms Almeida and Wolfenzon (2006) recently suggested the importance of raising outside equity to justify the creation of a new legal unit when exploiting a new business.

According to the financial perspective (henceforth FP) business groups are used by entrepreneurs to manipulate the ownership structure of new businesses to maximize their financial wealth. The legal autonomy of the new business gives the entrepreneur the opportunity to raise outside equity to finance new ventures. In the $F P$ it is taken for granted that the 'entrepreneur' retains control and management of the new business and that the minority shareholders are purely investors with no involvement in management. This model justifies the presence of business groups because entrepreneurs have advantages in being able to draw on the cash flow of their existing businesses to leverage further capital from outsiders who are in-

${ }^{6}$ In Appendix A we provide some examples of Italian business groups.

7 This approach has a long history which can be traced back to the seminal works by Berle and Means (1932) and Hilferding and Bottomore (1981). For a discussion see Almeida and Wolfenzon (2006, p. 2638). 
vesting in the new venture Within the financial explanation there is a debate on whether the internal capital market in business groups is used as a way of expropriating minority shareholders or to support controlled companies in periods of financial distress In general, the literature assumes that the tunnelling of resources among firms within groups advantages controlling shareholders.

The organizational perspective (henceforth $O P$ ) focuses on the organizational problems faced by entrepreneurs when developing new businesses. When considering entry into a new business, established entrepreneurs are faced with two problems: a) how to take advantage of the synergies with established businesses while guaranteeing the necessary autonomy of the new business; $b$ ) how to divide time and attention between the management of established businesses and the new venture.

The start-up phase is critical to the success of the new business and requires that the entrepreneur dedicates her/his time and attention to adjust planned actions to unforeseen events, and to deal with unpredictable contingencies typical of this initial phase. Yet as a habitual entrepreneur he or she still needs to devote time to running the other company(s). Establishing a new company rather than growing within the same one confers real advantages to the entrepreneur in addressing these problems. The legal autonomy granted to the new venture helps to focus resources and monitor results. In addition, and even more importantly, legal autonomy allows the entrepreneur to modify the ownership structure of the new business and give minority shareholdings to those involved in the start-up of the new venture, without diluting ownership of the main businesses. By involving other people in the start-up of new ventures, entrepreneurs overcome the problem of allocating their time between their established and new activities, and enhance their ability to enter new businesses while retaining ownership and control of already established firms.

In addition to the time allocation problem, the involvement of other people in the ownership and control of new businesses enables the entrepreneur to introduce and involve specialized human capital resources. Moreover, when starting a new business entrepreneurs need to provide incentives to key employees to protect from the risk of being expropriated of the sources of competitive advantages. One of the ways to prevent knowledge steal from key people is to involve them in the ownership thus entrenching them to the new business. In addition, the ownership of a minority share in the new business, allows the employee to become part of the entrepreneurial team thus providing further motivation. The latter arguments are more and more important because the sources of competitive advantage are shifting from physical assets to knowledge/intangible assets that can be more easily stolen by key employees.

The two perspectives ( $F P$ and $O P$ ) reach similar conclusions about the main reasons for setting up a new company, i.e. modifying the ownership 
structure of the new business, but for different reasons. The empirical relevance of these approaches can be assessed by highlighting their different predictions; specifically these relate to: i) when it is more likely for a firm to be part of a business group; ii) the ownership structure of the controlled firms.

According to the $F P$, "firms in pyramids are expected to be larger or to belong to capital intensive sectors" 8 As the required investment increases, firms are more likely to belong to business groups. For this reason a key variable to explain the presence of business groups is expected to be the amount of capital needed to set up a firm. In contrast, the organizational perspective emphasizes the importance of human capital in the creation of new firms. As a result, knowledge intensive firms are more likely to belong to business groups because of the need to involve in the entrepreneurial team specialized human resources.

As a result we compare the following contrasting hypotheses:

i.a) larger and more capital intensive firms are more likely to belong to business groups $(F P)$

i.b) knowledge intensive firms are more likely to belong to business groups (OP).

A key issue in both explanations of business groups is the ownership structure of companies. According to the FP the main reason to set up a business group is to separate cash flow rights and control rights of controlled companies (equity leverage mechanism). ${ }^{9}$ For this reason we expect that the ownership stake held by the entrepreneur in directly controlled company (head of the group) should be at least no smaller than the ownership stake held in companies controlled by other companies. We expect, therefore, that the ownership stake held by entrepreneurs in head companies is similar to the one held in standalone firms. Moreover, we expect the entrepreneurs to retain the minimum share to maintain the control of the business and the minority shares to be as higher as possible.

Within business group it is necessary to distinguish between firms directly owned by the entrepreneur and firms controlled by other firms, since it is only in the latter that the 'equity leverage' mechanism is at work. Just to give an intuition, let's consider Figure 1, Figure 2 and Figure 3.

8 Almeida and Wolfenzon (2006) use the term pyramid to refer to firms controlled by other firms.

${ }^{9}$ In contrast to the traditional 'equity leverage' argument Almeida and Wolfenzon (2006) states that: "It is possible to observe pyramids in which the controlling family has high cash flow stakes in member firms, in which case the separation between ownership and control is not large" (Almeida and Wolfenzon 2006, p. 2662). Moreover, since the Almeida and Wolfenzon (2006) model does not rely on the traditional argument of separating cash-flow from control rights, it accounts for situations characterized by high concentration of ownership in the controlled firms. 
Figure 1 - Example of a Vertical Business Group

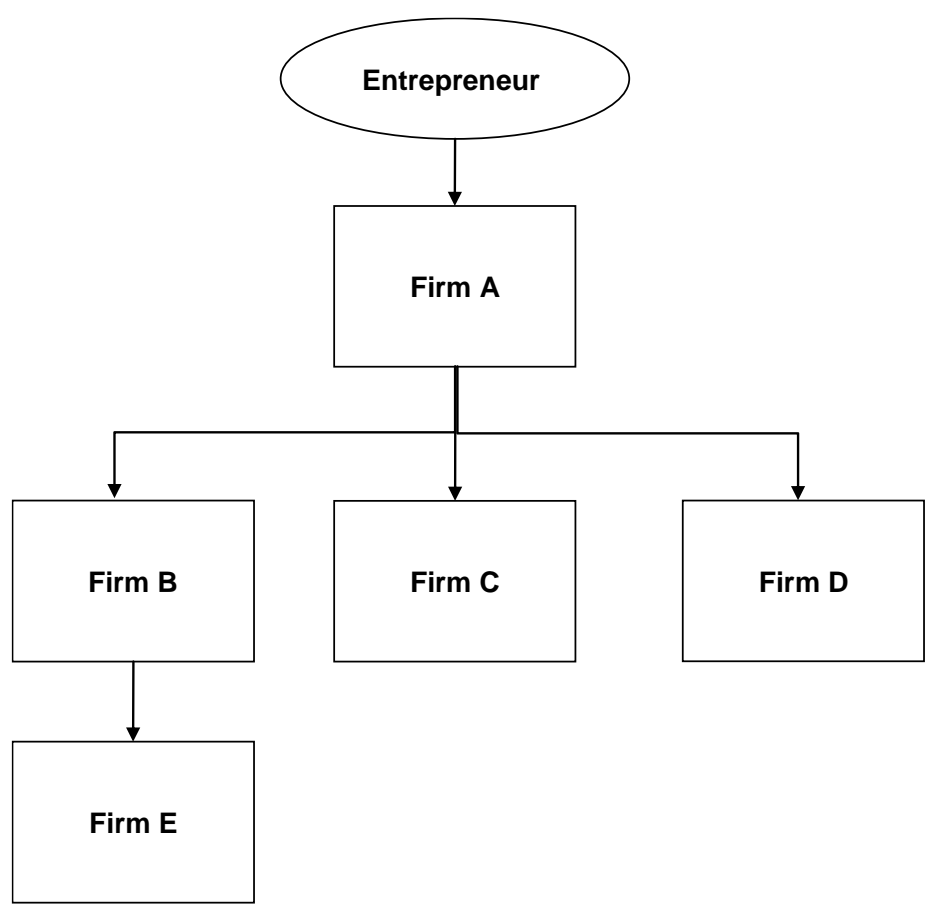

Figure 2 - Example of a Horizontal Business Group

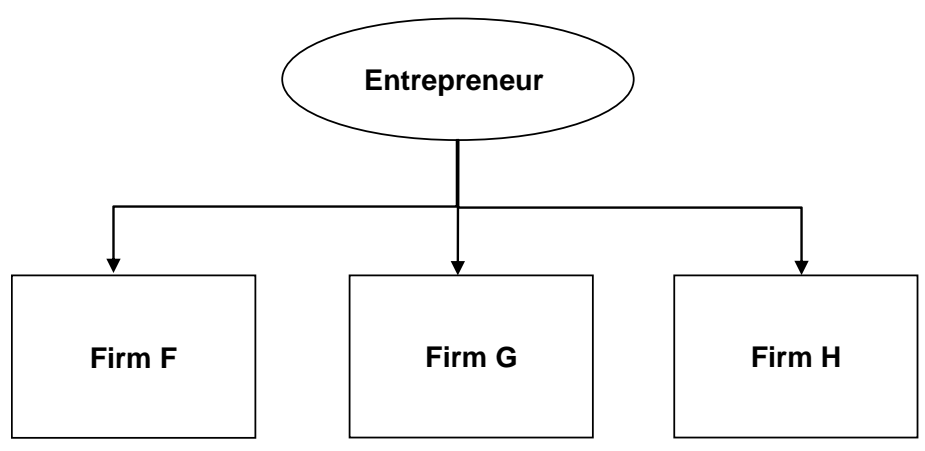




\section{Figure 3 - Example of a "Mixed" Business Group}

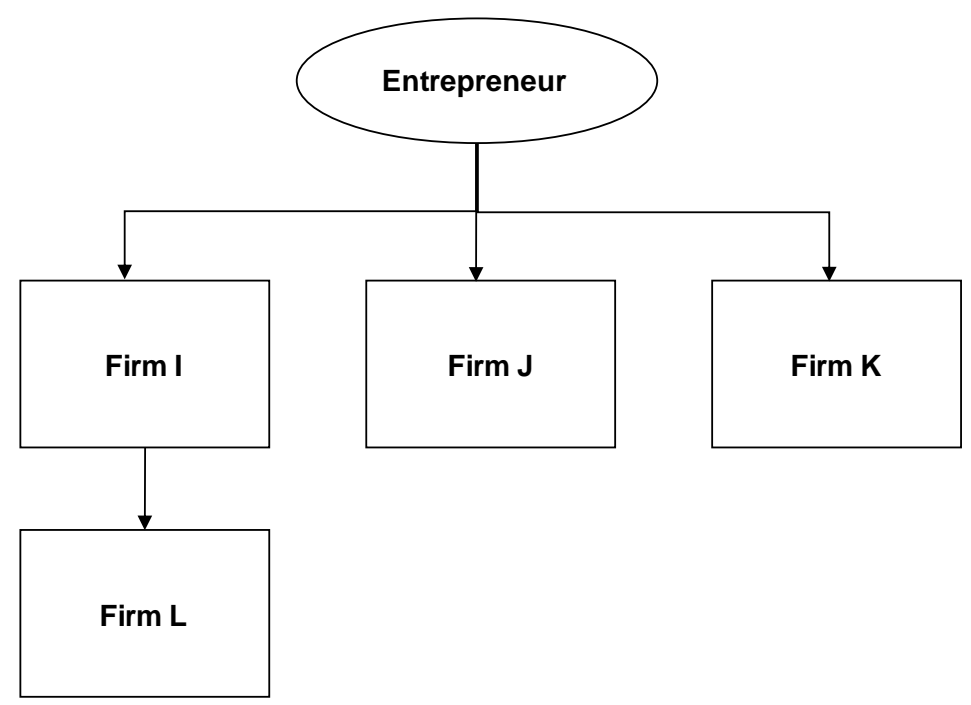

Figure 1 is an example of a so-called vertical business group (pyramid). In this kind of group there is a firm (A) which is at the head of the group. The head is the only firm which is directly controlled by the entrepreneur and which controls other firms, directly (e.g. firm B and C) or indirectly (e.g. firm D). In vertical groups the equity leverage mechanism is at work for all the affiliated firms but for the head (being directly controlled by the vertex).

Figure 2 is an example of a so-called horizontal group. In a horizontal group there is not a head: the 'head' is, with a little abuse of terminology, the entrepreneur himself since all firms are directly owned by the entrepreneur. For this reason in a horizontal group the equity leverage mechanism is not at work. Finally, Figure 3 presents a 'mixed' situation where the equity leverage mechanism is at work only for one firm $(\mathrm{L})$ which is owned by another firm (I).

In the empirical analysis, in order to assess the predictions of $F P$ we will check whether a firm in a business group is controlled directly by the entrepreneur or whether it is controlled by another firm.

In the $O P$ perspective minority stakes in new companies are sold with the aim of involving other people in the management of new firms; therefore, these stakes can be expected to be low since they are aimed primarily at providing incentives to people involved in the start-up and management of the new business and not to raise outside equity.

Therefore we can test the following alternative hypotheses:

ii.a) entrepreneur(s) are expected to hold smaller ownership stakes in firms controlled through other firms, relative to firms directly owned and controlled (FP)

ii.b) entrepreneur(s) are expected to hold greater ownership stakes in firms controlled through other firms, relative to firms directly owned and controlled (OP) 


\section{Data and Methodology}

In this paper we consider whether these theoretical approaches are consistent with empirical evidence of business groups in the small business sector. The study of these issues has been handicapped by the fact that national data on habitual entrepreneurs and small business groups are rarely collected. Most countries collect data on firms, with the assumption that it is firm performance rather than entrepreneurial performance that is of primary interest (Scott and Rosa, 1996).

To test the above hypotheses we use quantitative analysis based on secondary data derived from the Capitalia dataset which is based on a periodical survey (every three years) of a representative sample of about 4,000 Italian manufacturing firms with more than ten employees. In this study data refer to 2003. The Capitalia survey is particularly suited for our purposes since it requests information indicating whether a firm belongs to a business group, and what its position is within the group. Moreover, the dataset allows a detailed analysis of the ownership structure of firms since it has information on both ownership share and type of owner (person or legal entity). This information is relevant to our analysis since, as we have seen, the FP makes some predictions about the level of ownership concentration on the basis of the position of the company within the group and whether it is controlled directly by the family (head of the group) or through other companies. The Capitalia dataset does not provide information on the exact position of the firm within a group. Nevertheless, it asks companies belonging to a group whether: a) they control other companies but are not controlled by a company (head of the group); b) they are controlled by a company and control other companies (intermediate position); c) they are controlled by a company but do not control other companies (bottom of the group). The typology of owners and positions within the groups structure allow us to test the difference between the ownership structure of companies owned directly by a family, with those owned through established companies. Moreover, the dataset allows us to compare the differences between independent firms and those belonging to a business group. Although the study refers to Italy, we have no reason to believe that factors affecting the presence of business groups are different in Italy.

To test the implications of the two approaches discussed in the previous section we use Probit and OLS models. The Probit models are used to test which factors affect the probability of a firm to belong to a business group; the OLS models are used to analyse the ownership structure of companies within business groups.

We note that when testing hypothesis $i$ ) a reverse causality problem can occur, that is the affiliation to a business group can affect firms characteristics such as size, R\&D intensity, etc. The presence of endogeneity (i.e. one or more regressors correlated with the error term) will produce biased and 
inconsistent estimates of coefficients. To cope with endogeneity we use instrumental variables. In particular, as instruments we use the mean value of the variables at the industry level (2-digit Ateco). ${ }^{10}$ We use these instruments because of the absence of other variables that could be used as proper instruments. In the next section we discuss in more detail this issue.

\section{Table 2 - Variables Used in the Empirical Analysis}

\begin{tabular}{|c|c|}
\hline Variable & Description \\
\hline $\begin{array}{l}\text { Capital } \\
\text { intensity }\end{array}$ & Ratio between fixed assets and the annual sales \\
\hline $\begin{array}{l}\text { Human } \\
\text { capital }\end{array}$ & $\begin{array}{l}\text { Ratio between the number of employees endowed with a degree and } \\
\text { the total number of employees }\end{array}$ \\
\hline $\begin{array}{l}R \& D \\
\text { intensity }\end{array}$ & Ratio between R\&D expenses and the annual sales \\
\hline Firm size & Logarithm of employees of the firm \\
\hline Group size & Logarithm of employees of the group \\
\hline Age & Age of the firms in years \\
\hline Group & Dummy variable indicating whether a firms belongs to a group \\
\hline Person & $\begin{array}{l}\text { Dummy variable indicating whether the controlling owner is a person } \\
\text { (as opposed to a firm) }\end{array}$ \\
\hline Ownership & Share of the first (controlling) owner \\
\hline Sectors & Dummies for industry sectors based on Pavitt taxonomy ${ }^{1}$ : \\
\hline dummies & Supplier dominated (traditional sectors) \\
\hline & Scale intensive \\
\hline & Specialized supplier \\
\hline & - $\quad$ Science based \\
\hline Controlled & $\begin{array}{l}\text { Dummy variable indicating whether the firm is controlled by another } \\
\text { firm }\end{array}$ \\
\hline
\end{tabular}

(1) To control for industry features we use the Pavitt classification of sectors based on innovation patterns (Pavitt 1984). The classification distinguishes between four macro sectors: scale intensive, dominated suppliers, science based and specialized suppliers. In the estimates we use the supplier dominated sector as reference.

The Capitalia dataset contains data on 4,280 firms of which 1,386 belonging to business groups. Of the latter, 351 are directly controlled by families while the remaining are controlled by other companies. There is a large literature debating what a small firm is, and the complexities of defining a small firm (quantitatively and qualitatively - see for example). In contrast there is no literature on what may constitute a small business group. Should one take the individual firm as the unit of maximum size, or the aggregate of all the firms in the group? In our view the most important consideration is whether the group is based on the ownership of an entrepreneur (or family) and not part of a large publically owned corporation. Consequently we focus on owner managed small firms, and follow the EU definition of a small firm of comprising no more than 250 employees. When considering the overall group we restrict our analysis to groups with less than 500

\footnotetext{
${ }^{10}$ We use the Ateco classification which is in accordance with the Nace EU classification.
} 
employees; given that a group is made up of at least two companies, this ensures that the average size of companies belonging to groups is less than 250 employees. Thus firms with less than 250 employees are 3,079 of which 791 belonging to a group.

The original dataset has been integrated with data from company annual reports of 2001,2002, and 2003. Additional data on variables such as capital and knowledge intensity, needed to be obtained from the company annual reports. These were not available for all firms and all years, the dataset we use is thus made up of about 2,700 firms. It is possible that firms with no annual reports are the smallest, and this raises the possibility of bias. On checking, there appeared to be no noticeable difference between the sizes of firms which had and did not have annual reports. Table 2 shows the variables used in the empirical analysis, the ways in which they are calculated and whether they refer to firm or group level. Table 3 presents some descriptive statistics.

Table 3 - Summary Statistics - Firms with Less than 250 Employees - 2003

\begin{tabular}{|c|c|c|c|c|c|c|}
\hline & \multicolumn{4}{|c|}{ Firms belonging to groups } & \multirow{2}{*}{\multicolumn{2}{|c|}{$\begin{array}{l}\text { Stand alone firms } \\
\text { (No Group) }\end{array}$}} \\
\hline & \multicolumn{2}{|c|}{ Total } & \multicolumn{2}{|c|}{$\begin{array}{c}\text { Controlled } \\
\text { (firms controlled by } \\
\text { other firms) }\end{array}$} & & \\
\hline \multirow[t]{2}{*}{$\begin{array}{l}\text { Number of } \\
\text { observations }\end{array}$} & \multicolumn{2}{|c|}{791} & \multicolumn{2}{|c|}{609} & \multicolumn{2}{|c|}{2,288} \\
\hline & Mean & $\begin{array}{l}\text { Standard } \\
\text { deviation }\end{array}$ & Mean & $\begin{array}{l}\text { Standard } \\
\text { deviation }\end{array}$ & Mean & $\begin{array}{l}\text { Standard } \\
\text { deviation }\end{array}$ \\
\hline $\begin{array}{l}\text { Capital } \\
\text { intensity }\end{array}$ & .3468 & 6479 & 3189 & .3272 & .2886 & .3138 \\
\hline Human capital & .072 & .087 & .072 & .090 & .043 & .062 \\
\hline R\&D intensity & .013 & .091 & .009 & .038 & .006 & .051 \\
\hline $\begin{array}{l}\text { Firm size } \\
\text { (employees) }\end{array}$ & 87.12 & 60.94 & 84.85 & 59.94 & 49.46 & 41.80 \\
\hline $\begin{array}{l}\text { Group size } \\
\text { (employees) }\end{array}$ & $2,317.76$ & $14,250.16$ & $3,015.99$ & $16,547.2$ & & \\
\hline Ownership & $75.06 \%$ & 27.75 & $81.07 \%$ & 24.96 & $53.36 \%$ & 26.32 \\
\hline Age (years) & 25.5 & 18.7 & 23.9 & 18.6 & 28.1 & 17.9 \\
\hline
\end{tabular}

Elaborations on Capitalia data set.

\section{Empirical analysis}

The first hypothesis we test is that larger or capital intensive firms are more likely to belong to business groups $(F P)$, and its correspondent "organizational" counterpart $(O P)$ - i.e. knowledge intensive firms are more likely to belong to business groups.

In order to test these hypotheses we use fixed assets (in logarithmic 
terms) as a proxy of capital investment of the firm. Moreover, we use the share of employees with a degree on total employees as a proxy for the importance of human capital and the ratio between R\&D expenses and sales to measure the knowledge intensive of the firm. We also control for the size of the firms (employees in logarithmic terms) and the age of the firm.

Before introducing Probit estimations we present the correlations matrix between the independent variables of the regressions (Table 4).

Table 4 - Correlation Matrix of Independent Variables Used in the Regression for the Companyâs Affiliation to a Business Group (2003)

\begin{tabular}{lcccccc}
\hline & Capital Intensity & Human capital & $\begin{array}{c}\text { R\&D } \\
\text { intensity }\end{array}$ & $\begin{array}{c}\text { Firm } \\
\text { Size }\end{array}$ & $\begin{array}{c}\text { Group } \\
\text { size }\end{array}$ & Age \\
\hline Capital & 1.000 & & & & & \\
intensity & & & & & & \\
Human capital & .0899 & 1.000 & & & & \\
R\&D intensity & .4358 & .1106 & 1.000 & & & \\
Firm Size & .0557 & .1049 & .0502 & 1.000 & & \\
Group size & -.0267 & .0117 & -.0125 & .4061 & 1.0000 & \\
Age & .0333 & -.0103 & .0355 & .1247 & -.0893 & 1.000 \\
\hline \hline
\end{tabular}

Elaborations on Capitalia data set.

The probability for a firm to belong to a group (hypothesis 1 ) is tested using Probit estimates. The dependent variable (Group) is a dummy variable which equals 1 if the company belongs to a business group and 0 if the company is an unaffiliated one. In order to tackle endogeneity problems we will use instruments for the explanatory variables: Capital intensity, Human capital, RED intensity, Firm size. As instruments as said above we use the mean values at 2-digit industry level. The regressions are carried out by using the ivprobit-STATA command. In order to check the validity of instruments (weak instruments) we also run a linear regression model with instrumental variables. In this case, in order to perform a test of overidentified restrictions we add another instrument which is: the mean value of log of total Assets at two-digit ATECO. We perform both Sargan and Bassman tests of overidentified restrictions for the 2SLS estimator. Furthermore we run the model by requiring robust standard errors and then obtaining Wooldridge's score test of overidentified restrictions (which is robust to heteroskedasticity). All tests do not reject the null hypotheses that the instruments are uncorrelated with the error term.

We note that the variable Human capital is highly significant in all specifications, while the variable Capital intensity is less significant and non robust to various specifications. The strong effect of size in influencing the probability of being in a group is confirmed by the relevance and significance of the firm size variable and supports the FP. Overall these results are in accordance with both the predictions of the financial and the organizational perspectives (Table 5). In this sense the organizational and the financial ex- 
Table 5 - Probability of a Firm Belonging to a Business Group (Z-Values in Parentheses)

\begin{tabular}{lcccc}
\hline \hline & \multicolumn{4}{c}{ Probit $^{\mathbf{a}}$} \\
\cline { 2 - 5 } Capital intensity & $\mathbf{1}$ & $\mathbf{2}$ & $\mathbf{3}^{\mathbf{b}}$ & $\mathbf{4}^{\mathbf{b}}$ \\
& $.5981^{*}$ & .5375 & 1.2289 & $1.0924^{*}$ \\
Human Capital & $(1.84)$ & $(1.38)$ & $(1.63)$ & $(1.69)$ \\
& $6.4711^{* * *}$ & $6.4642^{* * *}$ & $8.4490^{* * *}$ & $7.1526^{* *}$ \\
Firm size & $(3.06)$ & $(3.07)$ & $(2.83)$ & $(2.31)$ \\
& $.8639^{* * *}$ & $.8015^{* *}$ & $1.3300^{* * *}$ & .7877 \\
Age & $(2.96)$ & $(2.17)$ & $(2.91)$ & $(1.28)$ \\
& $-.0108^{* * *}$ & $-.0106^{* * *}$ & $-.01509^{* * *}$ & $-.0127^{* * *}$ \\
R\&D intensity & $(-4.88)$ & $(-4.46)$ & $(-4.72)$ & $(-3.75)$ \\
& & .7987 & & 6.9603 \\
Scale & & $(0.28)$ & & $(1.00)$ \\
Specialized & $.2034^{* *}$ & $.2054^{* *}$ & $.2350^{* *}$ & $.2438^{* *}$ \\
Science & $(2.39)$ & $(2.43)$ & $(2.33)$ & $(2.57)$ \\
$\mathrm{N}^{\circ}$ of observation & .0598 & .0627 & .0083 & .0651 \\
Wald Chi ${ }^{2}$ & $(0.58)$ & $(0.61)$ & $(0.06)$ & $(0.46)$ \\
& -.0363 & -.0580 & -.1301 & $-.1235^{* *}$ \\
Wald test of exogeneity: Chi ${ }^{2}$ & $(-0.17)$ & $(0.24)$ & $(-0.45)$ & $(-0.45)$ \\
& 2,678 & 2,678 & 2,337 & 2,337 \\
\hline \hline
\end{tabular}

a. The regression includes a constant term.

b. Firms carrying out operations of acquisition/hiving off in the period considered are excluded.

Legend: ** significant at $1 \%$; ** significant at $5 \%$; * significant at $10 \%$.

Elaborations on Capitalia data set.

planations seem to be complementary to each other. The variable used as a proxy for the knowledge intensity of production (RED intensity) is never statistically significant.

Table 6 - Share of Ownership of Companies Belonging to Business Groups and T-test of Mean Differences - 480 Groups with Less than 500 Employees - 2003 (Percentage Values)

\begin{tabular}{|c|c|c|c|c|c|c|c|c|}
\hline \multirow{3}{*}{ Owner } & \multirow{3}{*}{ Standalone } & \multirow{3}{*}{ Head } & \multirow{3}{*}{\multicolumn{2}{|c|}{ Intermediate Bottom }} & $t_{\text {test }}{ }^{\mathrm{a}}$ & t test ${ }^{\mathrm{a}}$ & t test te $^{\mathrm{a}}$ & t test ${ }^{a}$ \\
\hline & & & & & \multicolumn{4}{|c|}{ Head/Stand. Head/Interm. Head/Bottom Interm./Bottom } \\
\hline & & & & & $\operatorname{Pr}(|\mathrm{T}|>|\mathrm{t}|)$ & $\operatorname{Pr}(|\mathrm{T}|>|\mathrm{t}|)$ & $\operatorname{Pr}(|T|>|t|)$ & $\operatorname{Pr}(|\mathrm{T}|>|\mathrm{t}|)$ \\
\hline First owner & 53.4 & 52.3 & 71.9 & 79.2 & 0.559 & $0.000 * *$ & $0.000 * *$ & $0.032 *$ \\
\hline Second owner & 24.9 & 24.0 & 14.7 & 13.5 & 0.394 & $0.000 * *$ & $0.000 * *$ & 0.723 \\
\hline Third owner & 10.7 & 9.7 & 6.0 & 4.0 & 0.486 & $0.005^{* *}$ & $0.005^{* *}$ & 0.137 \\
\hline
\end{tabular}

a Legend: two-tailed t-test for mean equality; ** significant at $1 \%$; * significant at $5 \%$.

Source: Capitalia data set

The variable Age is significant in all specifications and its coefficient is negative. This means that affiliated firms are more likely to be younger 
than independent firms.

Finally, we note that according to the Wald test for exogeneity we reject the null hypotheses that there is no endogeneity.

The Capitalia dataset shows that the share of ownership of controlled companies is quite high and generally much higher than is needed to secure control; this is in accordance with the predictions of the $O P$ and contrasts with FP. This means that separating cash flow from control rights is not always the justification for creating a group structure (Table 6). We performed t-tests for mean equalities of ownership shares between standalone firms and firms belonging to groups. The t-test confirms that there is no significant difference in ownership shares between standalone and head of groups while there are significant differences in ownership shares between the head of groups and controlled companies (intermediate and bottom companies).

Table 7 - Share of the First Owner in Companies Belonging to Groups (T-test in Parenthesis)

\begin{tabular}{lcccc}
\hline & \multicolumn{4}{c}{ OLS $^{\text {a }}$} \\
\cline { 2 - 5 } Person & 1 & 2 & 3 & 4 \\
& $-18.2007^{* * *}$ & $-18.1291^{* * *}$ & $-18.7448^{* * *}$ & $-18.4127^{* * *}$ \\
Controlled & $(-5.14)$ & $(-5.11)$ & $(-5.27)$ & $(-5.18)$ \\
& $17.8677^{* * *}$ & $18.2751^{* * *}$ & $16.7964^{* * *}$ & $18.7676^{* * *}$ \\
Firm size & $(4.94)$ & $(5.04)$ & $(4.72)$ & $(5.10)$ \\
& $2.9789^{*}$ & $2.8668^{*}$ & & $4.0553^{* *}$ \\
R\&D intensity & $(1.88)$ & $(1.80)$ & & $(2.07)$ \\
& & .2966 & .5993 & .5137 \\
Group size & & $(0.07)$ & $(0.33)$ & $(0.12)$ \\
& & & .7449 & -2.1332 \\
Scale & & & $(0.40)$ & $(-0.95)$ \\
& & -2.9982 & -3.2536 & -3.1512 \\
Special & & $(-0.78)$ & $(-0.84)$ & $(-0.82)$ \\
& & 4.2606 & 4.4738 & 4.1415 \\
Science & & $(1.49)$ & $(1.57)$ & $(1.45)$ \\
& & 6.7051 & 5.8813 & 7.0457 \\
Number of observations & 370 & $(1.10)$ & $(0.98)$ & $(1.16)$ \\
F & & 370 & 370 & 370 \\
$\mathrm{R}^{2}$ & 52.37 & 25.73 & 25.33 & 22.83 \\
\hline
\end{tabular}

a. Robust standard errors in parentheses; the regression also includes a constant term.

Legend: ${ }^{* *}$ significant at $1 \%$; ${ }^{* *}$ significant at $5 \%$; * significant at $10 \%$.

Elaborations on Capitalia data set.

The Capitalia dataset also shows that when a company is controlled by another one, the average share is higher than when it is at the head of the group and is directly controlled by the entrepreneur. In fact, the main difference in ownership concentration is observed when we compare firms 
owned directly by the entrepreneur with companies controlled by other companies; in the latter case, the position within the group is less relevant to ownership concentration.

In order to analyse prediction ii.a), we assume that ownership concentration is related to variables other than type of owner (physical person or company) and the position of the company in the group. To assess the robustness of the previous analysis, we performed a multivariate analysis, taking into account other variables that potentially might influence ownership concentration. ${ }^{11}$

The main explanatory variables are Person and Controlled. According to the FP we expect a positive coefficient for the variable Person since (as said above) for companies owned directly by the entrepreneur the equity leverage mechanism is not at work. For symmetrical reasons we expect a negative coefficient for the variable Controlled.

Moreover we control for company size (measured by the number of employees), overall size of the group and the technological regime to which the company belongs. For this last we use ratio of R\&D expenditure on sales as a proxy for the firm's product innovation intensity. The expectation is that the coefficient of this variable will be positive because of the greater difficulty involved in raising external capital (equity) for R\&D investment (due to higher information asymmetries). In the case of company size, we expect a negative coefficient, the reason being that the larger the company, the greater will be the need for external capital. In the case of the overall size of the group, we do not have a-priori expectations. On the one hand, a larger group should be able to generate enough internal cash-flow to finance new companies on its own; on the other hand, the size of the group can have a positive influence on the ability to raise external capital. The result of the multivariate analysis is presented in Table 7.

The multivariate estimates do not confirm hypothesis ii.a): the share of the first (controlling) owner is higher when the company is controlled by another company, than when it is controlled by a physical person.

The technological intensity of production has the expected sign, but is not statistically significant; this is probably due to measurement problems. The size of the company and the size of the group are not statistically significant.

We can conclude that hypothesis ii.a) is rejected by the data, while hypothesis ii.b) is confirmed.

\footnotetext{
${ }^{11}$ Also in this case we consider possible endogeneity problems. We use an instrumental variable approach (2SLS). As instruments we use the average of the original variables (Firm size, RED intensity) at 2-digit Ateco. The Durbin and Wu-Hausman tests do not reject the null hypothesis that the variable(s) under consideration are exogenous. Therefore we use OLS estimation which is more efficient.
} 


\section{Conclusions}

Until recently the formation and presence of business groups was associated with large businesses, and explained predominantly by financial theories. The presence of business groups in the small business sector suggests that there are alternative theories, based on the entrepreneurial and organizational strategies of entrepreneurs. Are both perspectives relevant to understanding business group formation in the small firms sector, or are the two explanations mutually exclusive in their respective contexts? This paper sheds light on this issue by comparing both financial and entrepreneurial/organizational perspectives which may explain the formation and characteristics of business groups in the small business sector.

These two perspectives have different implications for the role played by minority shareholders in controlled firms. The financial explanation highlights the importance of raising outside equity to separate cash flow rights from control rights and maximize the return on the capital invested by the entrepreneur. The entrepreneurial/organizational explanation considers the raising of outside equity as a mechanism to incentivize new human resources, thus strengthening the entrepreneurial team involved in the start-up and management of the new businesses. In so doing the establishment of a new firm and its addition to the business group provides a more efficient mechanism for organising and managing entrepreneurial diversification which would otherwise could been incorporated less efficiently within an existing firm (Wiklund and Shepherd, 2008).

Two hypotheses were derived from these contrasting perspectives for detailed empirical analysis. The first hypothesis, i.e. that firms controlled through business groups are expected to be larger and more capital intensive $(F P)$ is supported by the empirical evidence, but the counterpart hypothesis $(O P)$, i.e. that firms in business groups are more likely to be knowledge intensive (in terms of human resources employed by the firm) is also supported by the empirical evidence. In this sense both explanations seem to be complementary to each other.

The greater presence of business groups in capital intensive sectors results from entrepreneurs using the cash flow accumulated by the established firm to leverage equity. According to the FP this is often done at the expense of minority shareholders. The 'expropriation' of minority shareholders crucially depends on the degree of separation between cash flow rights and control rights (i.e. the ownership shares of minority shareholders). According to this mechanism we expect that the ownership share in indirectly controlled companies is lower than the ownership share of the entrepreneurs in the directly controlled companies. The empirical evidence, however, shows the contrary, that the entrepreneur's share is lower in directly controlled firms than in those indirectly controlled. This finding is compatible with the $O P$ but less reconcilable with the FP. Furthermore given 
that in many cases ownership concentration is so high, this is less reconcilable with the aim of separating cash-flow rights from control rights.

For these reasons our empirical results confirm that the entrepreneurial explanation provides a strong alternative explanation for the presence and characteristics of business groups in the small business sector.

Our ability to research these issues quantitatively has been made possible by being able to access the Capitalia database in Italy which is rare amongst data bases of firms in providing information on ownership links across firms, and the ability to differentiate between vertical and horizontal business groups. For this reason Italian firms have provided an important context to explore these hypotheses. This study thus confirms the importance of being able to establish data bases of firms capable of identifying ownership linkages between portfolio entrepreneurs and the firms they have an ownership stake in (Scott and Rosa, 1996). How far we may be able to generalise further from these findings will depend to a large extent on the ability of future studies to identify and explore similar data bases.

The empirical analysis has some limitations. The most important refers to the variables available. In order to achieve a more precise investigation of our hypotheses (in terms of ownership shares and sector of activity) we should consider new-born firms in business groups, i.e. firms just after their foundation, and the involvement of minority shareholders in the management of the new-born firms. This would require ad hoc collection of data. Despite this limitation, the original contribution of this paper is to show the relevance of the 'entrepreneurial/organizational perspective', and to highlight among other things, the role of human capital in explaining the presence of business groups. This is a crucial dimension that is mostly missing from the 'financial' explanatory approach. Future research should focus on related theoretical and empirical issues.

In terms of theoretical investigation, it might be fruitful to integrate models considering the role of human capital in the creation of new ventures in the context of business groups. In relation to the empirical evidence, the present study 'indirectly' tests the compatibility of the organiz ational approach with the available data, on the basis of some implications derived from this approach. Empirical analysis would benefit from the development of a more formal model to derive testable hypotheses. Also, analysis of the involvement of minority shareholders in the management of new companies would be useful in order to assess the relevance of the organizational approach. 


\section{References}

Almeida, H., Park, S. Y., Subrahmanyam, M. G., Wolfenzon, D., 2011. The Structure and Formation of Business Groups: Evidence from Korean Chaebols. Journal of Financial Economics 99, 447-475. doi:10.1016/j.jfineco.2010.08.017

Almeida, H., Wolfenzon, D., 2006. A Theory of Pyramidal Ownership and Family Business Groups. Journal of Finance LXI, 2637-2680. doi:10.1111/j.1540-6261.2006.01001.x

Ardichvili, A., Cardozo, R., Ray, S., 2003. A Theory of Entrepreneurial Opportunity Identification and Development. Journal of Business Venturing 18, 105-123. doi:10.1016/S0883-9026(01)00068-4

Bertrand, M., Mehta, P., Mullainathan, S., 2002. Ferreting out Tunneling: An Application to Indian Business Groups. Quarterly Journal of Economics 117, 121-148. doi:10.1162/003355302753399463

Birley, S., Westhead, P., 1993. A Comparison of New Businesses Established by 'Novice' and 'Habitual' Founders in Great Britain. International Small Business Journal 12, 38-60. doi:10.1177/0266242693121003

Bolton, J. E., 1971. Small Firms. Report of the Committee of Inquiry on Small Firms, London.

Carter, S., Ram, M., 2003. Reassessing Portfolio Entrepreneurship. Small Business Economics 21, 371-380. doi:10.1023/A:1026115121083

Cayssialis, J.-L., Kremp, E., Peter, C., 2007. Dix Années de Dynamique Financière Des PME En France, Paris, Banque de France Bulletin, 165.

Chabanas, N., 2002. Les Entreprises Francaises Des Groupes Vues a Travers Les Enquetes 'Liaisons Financieres' de 1980 a 1999, INSEE, Paris.

Colpan, A. M., Hikino, T., Lincoln, J. R., 2010. The Oxford Handbook of Business Groups, Oxford, Oxford University Press. doi:10.1093/oxfordhb/9780199552863.001.0001

Eurostat, 2003. Business Register Recommendations Manual. Methods and Nomenclatures.

Gifford, S., 1998a. Limited Entrepreneurial Attention and Economic Development. Small Business Economics 10, 17-30. doi:10.1023/A:1007966215575

Gifford, S., 1998b. The Allocation of Limited Entrepreneurial Attention, Norwell, Mass., Kluwer Academic Publishers. doi:10.1007/978-1-46155605-3 
Gopalan, R., Nanda, V., Seru, A., 2007. Affiliated Firms and Financial Support: Evidence from Indian Business Groups. Journal of Financial Economics 86, 759-795. doi:10.1016/j.jfineco.2006.09.008

Granovetter, M., 1995. Coase Revisited: Business Groups in the Modern Economy. Industrial and Corporate Change 4, 93-130. doi:10.1093/icc/4.1.93

Greene, W. H., 2005. Econometric Analysis, Upper Saddle River, N.J., Prentice Hall.

Hamelin, A., 2011. Small Business Groups Enhance Performance and Promote Stability, Not Expropriation. Evidence from French SMEs. Journal of Banking \& Finance 35, 613-626. doi:10.1016/j.jbankfin.2010.07.025

Hilferding, R., Bottomore, T. B., 1981. Finance Capitalâ': A Study of the Latest Phase of Capitalist Development, London; Boston, Routledge \& Kegan Paul.

Iacobucci, D., 2002. Explaining Business Groups Started by Habitual Entrepreneurs in the Italian Manufacturing Sector. Entrepreneurship and Regional Development 14, 31-48. doi:10.1080/08985620110096636

Iacobucci, D., Rosa, P., 2010. The Growth of Business Groups by Habitual Entrepreneurs: The Role of Entrepreneurial Teams. Entrepreneurship Theory \& Practice 34, 351-377. doi:10.1111/j.1540-6520.2010.00378.x

Khanna, T., Yafeh, Y., 2007. Business Groups in Emerging Markets: Paragons or Parasites?. Journal of Economic Literature 45, 331-372. doi:10.1257/jel.45.2.331

Lechner, C., Leyronas, C., 2009. Small-Business Group Formation as an Entrepreneurial Development Model. Entrepreneurship: Theory \& Practice 33, 645-667. doi:10.1111/j.1540-6520.2009.00320.x

Lhuillery, S., 2011. The Impact of Corporate Governance Practices on RD Efforts: A Look at Shareholders Rights, Cross-Listing and Control Pyramid. Industrial and Corporate Change 20, 1475-1513. doi:10.1093/icc/dtr022

Loiseau, H., 2001. Des Groupes de La Taille D'une PME. Un Phenomen En Plein Essor. INSEE Première.

Morck, R., 2003. Why Some Double Taxation Might Make Sense: The Special Case of Inter-Corporate Dividends. NBER Working Paper.

Morck, R., Wolfenzon, D., Bernard, Y., 2005. Corporate Governance, Economic Entrenchment, and Growth. Journal of Economic Literature 43, 655720. doi:10.1257/002205105774431252 
Morck, R., Yeung, B., 2003. Agency Problems in Large Family Business Groups. Entrepreneurship Theory \& Practice 27, 367-382. doi:10.1111/1540-8520.t01-1-00015

Morck, R., Yeung, B., 2004. Family Control and the Rent-Seeking Society. Entrepreneurship: Theory \& Practice 28, 391-409. doi:10.1111/j.15406520.2004.00053.x

Pavitt, K., 1984. Sectoral Patterns of Technical Change: Towards a Taxonomy and a Theory. Research Policy 13, 343-373. doi:10.1016/00487333(84)90018-0

Rajan, R. G., Zingales, L., 2000. The Governance of the New Enterprise. NBER Working Paper 7958.

Rajan, R. G., Zingales, L., 2001. The Firm as a Dedicated Hierarchy: A Theory of the Origins and Growth of Firms. Quarterly Journal of Economics 116, 805-852. doi:10.1162/00335530152466241

Rosa, P., Scott, M., 1996. Portfolio Entrepreneurs: Some Empirical Evidence on the Multiple Ownership or Control of SMEs, and Its Implication for Our Understanding of Start-Up and Growth. In Donckels, R., Miettinen, A., (Eds.), Research in entrepreneurship and small business: Entrepreneurship and SME research; on its way to the next millenium, Brussels, Aldershot, pp. 113-126.

Rosa, P., Scott, M., 1999. The Prevalence of Multiple Owners and Directors in the SME Sector: Implications for Our Understanding of Startup and Growth. Entrepreneurship and Regional Development 11, 21-38. doi:10.1080/089856299283272

Thorgren, S., Wincent, J., 2013. Passion and Habitual Entrepreneurship. International Small Business Journal 33, 2, 216-227. doi:10.1177/0266242613487085

Ucbasaran, D., Alsos, G.-A., Westhead, P., Wright, M., 2008. Habitual Entrepreneurs. Foundations and Trends in Entrepreneurship 4, 309-450. doi:10.1561/0300000014

Ucbasaran, D., Westhead, P., Wright, M., 2008 Habitual Entrepreneurs, Cheltenham, UK, Edward Elgar.

Westhead, P., Ucbasaran, D., Wright, M., 2003. Differences Between Private Firms Owned by Novice, Serial and Portfolio Entrepreneurs: Implications for Policy Makers and Practitioners. Regional Studies 37, 187-200. doi:10.1080/0034340022000057488 
Westhead, P., Wright, M., 1998a. Novice, Portfolio, and Serial Founders in Rural and Urban Areas. Entrepreneurship Theory and Practice 22, 63-100.

Westhead, P., Wright, M., 1998b. Novice, Portfolio, and Serial Founders: Are They Different?. Journal of Business Venturing 13, 173-204. doi:10.1016/S0883-9026(97)90002-1

Westhead, P., Wright, M., Ucbasaran, D., 2005. Novice, Serial and Portfolio Entrepreneur Behaviour and Contributions. Small Business Economics 25, 109-132. doi:10.1007/s11187-003-6461-9

Wiklund, J., Shepherd, D. A., 2009. The Effectiveness of Alliances and Acquisitions: The Role of Resource Combination Activities. Entrepreneurship: Theory \& Practice 33, 193-212. doi:10.1111/j.1540-6520.2008.00286.x 


\section{Appendix A Examples of Italian business groups}

In the large firm sector business groups are conglomerate structures operating in several sectors. A typical example for Italy is the CIR group (controlled by di De Benedetti family) operating in four sectors: energy, media, automotive and healthcare. The prevailing organization of such groups presents a holding company at the vertex of the group and several subholdings controlling the companies in specific sectors (see Figure A1). In 2012 the CIR group had about 14,000 employees and generated a turnover of about 5 billion euros through the control of more than one hundred companies in Italy and abroad.

\section{Figure A1 - The CIR Group}

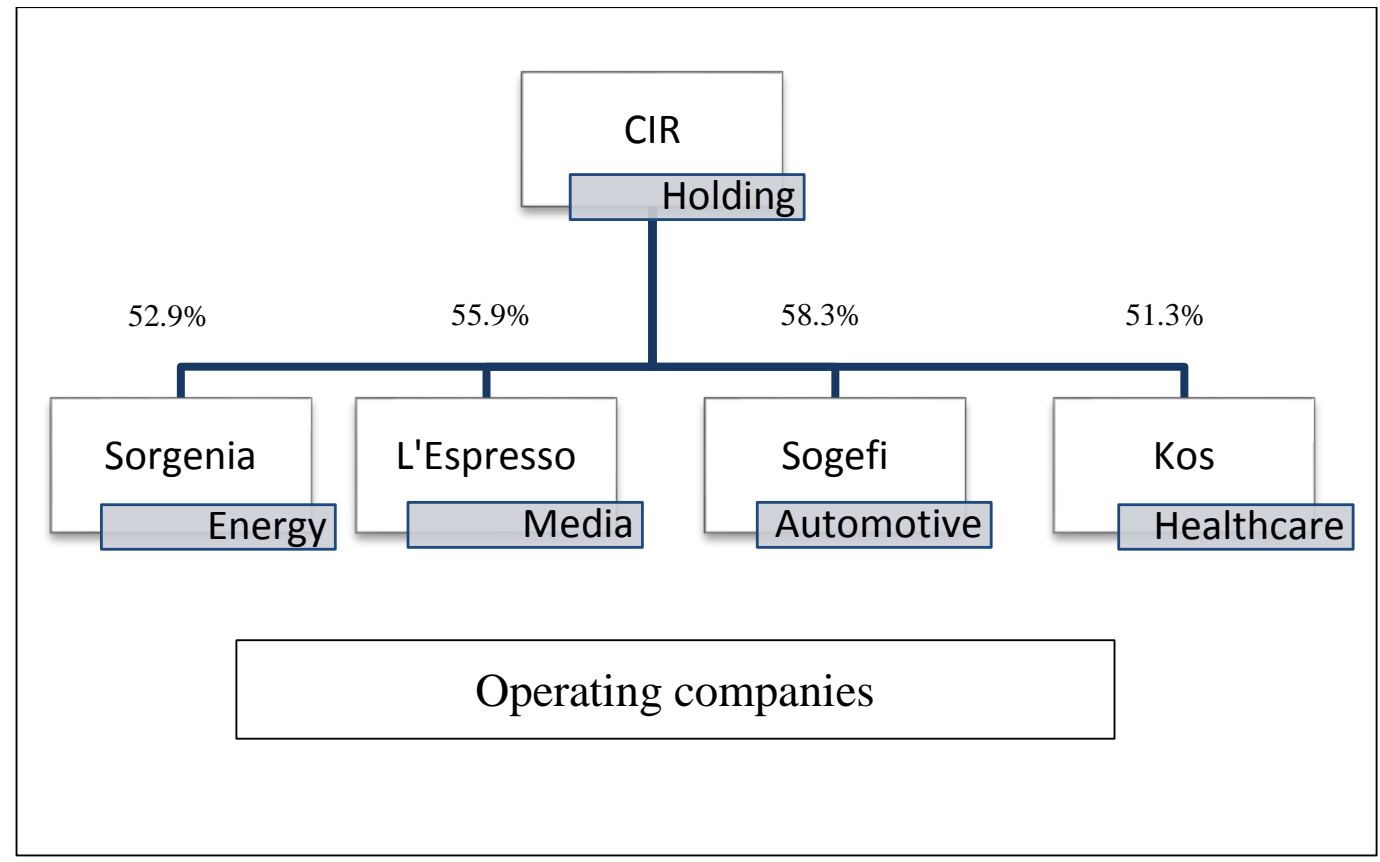

Small and medium sized groups are more often operating in the same sectoror in related sectors. Companies are created to exploit specific market segments or to integrated activities along the production chain. An example of medium sized groups is the Elica group (see Figure A2). The head of the group, listed at Milan stock exchange, is an operating company producing cooker hoods. All the companies within the group produce cooker hoods or provide services and components to the affiliated companies. In 2012 the group had a consolidated turnover of 385 million Euros and about 3,000 employees.

In small groups companies are sometimes directly owned by the entrepreneur and other shareholders; however the prevailing structure is the vertical structure (pyramid) in which a company owns shares in one or a 
few companies.

Examples of such groups are the Somacis group and the Lube group; the first operating in the production of printed circuit boards and touch screen devices; the second in the production of kitchen furniture.

The Somacis group is composed of height companies, four of which operating abroad (see Figure A3). The head of the group is a holding company. Of the three companies controlled by the head, two produce printed circuit boards and one (Tastitalia) touch screen devices. In 2012 the Somacis group had a consolidate turnover of 60.7 million Euros.

The Lube group is composed of six companies (see Figure A4). The head of the group is a holding company. The controlled companies operate in the production of different types of kitchen furniture or provide services for the same production. In 2012 the Lube group had a consolidated turnover or 147.5 million euros. 
Figure A2 - The Elica Group

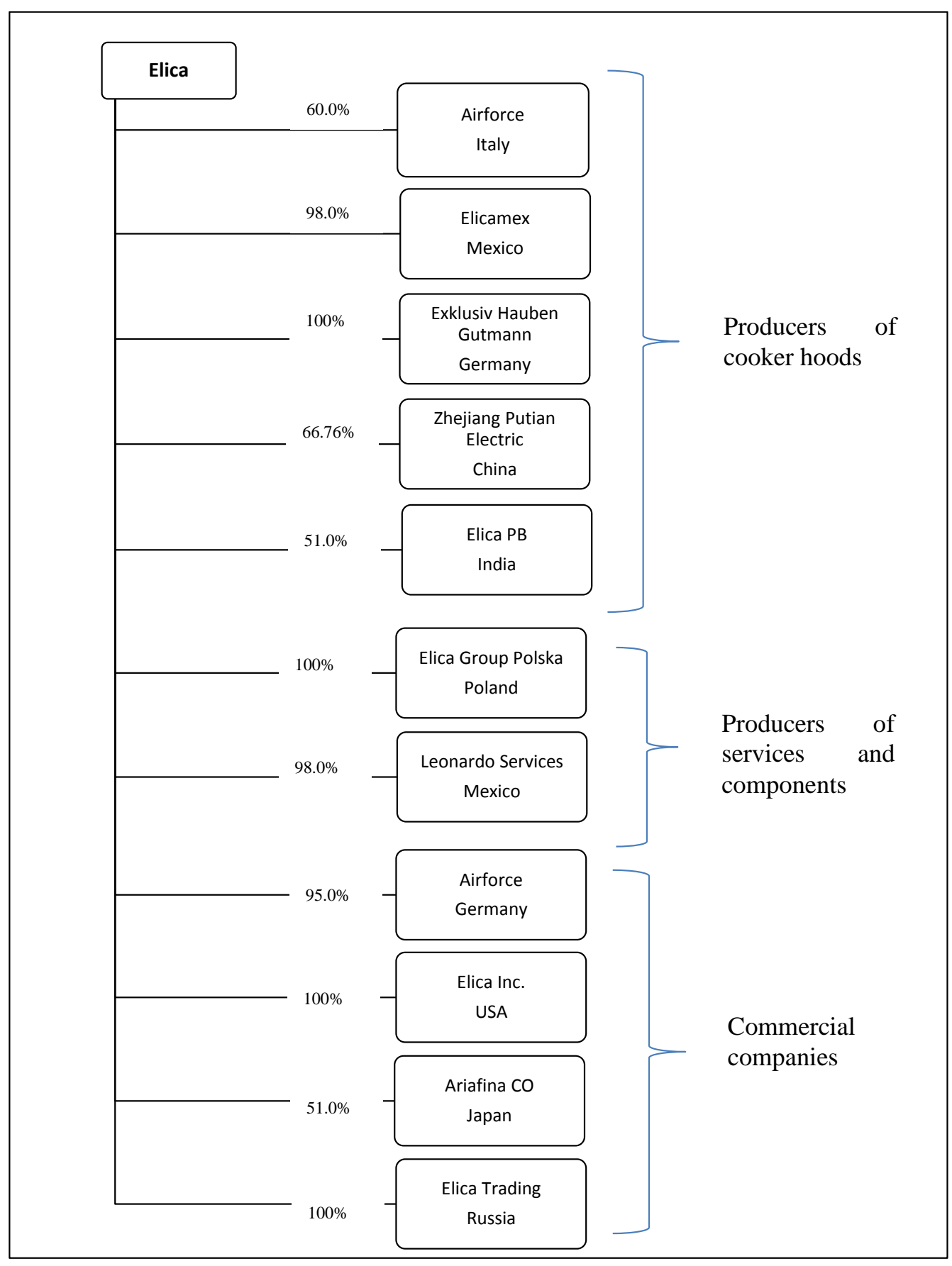




\section{Figure A3 - The Somacis Group}

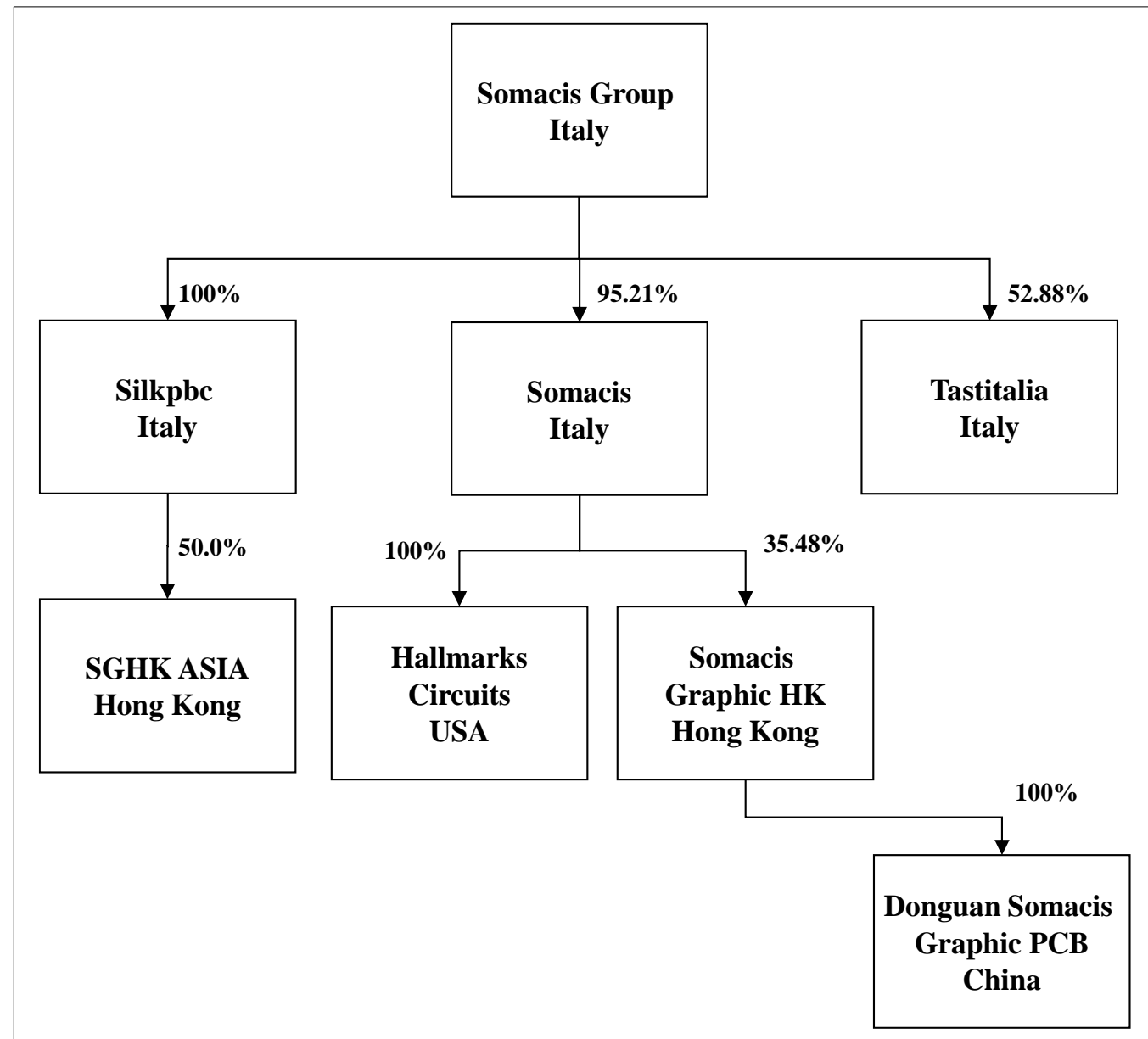

Figure A4 - The Lube Group

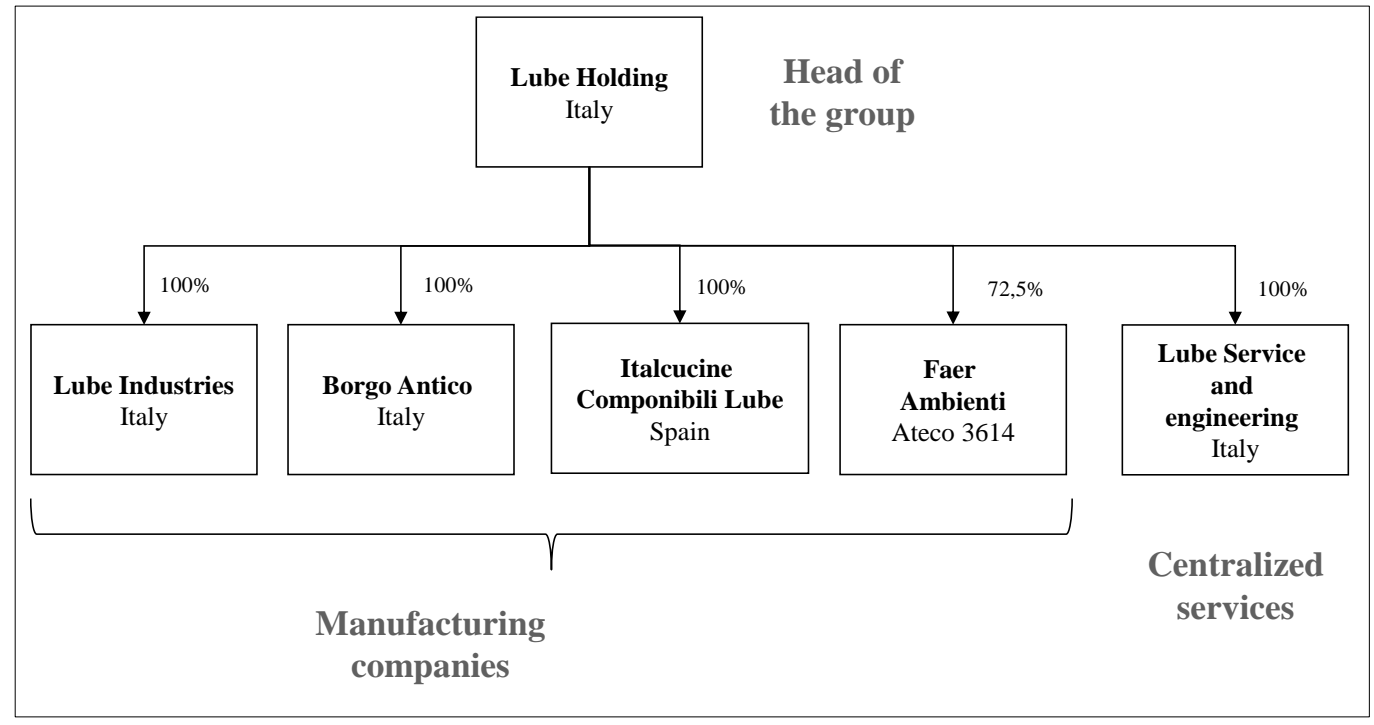

